\title{
Phylogenetic Diversity of Phytopathogenic Mycoplasmalike Organisms
}

\author{
SHIGETOU NAMBA, ${ }^{1 *}$ HIROSHI OYAIZU, ${ }^{2}$ SHOSUKE KATO,${ }^{3}$ SETSUO IWANAMI, ${ }^{3}$ \\ AND TSUNEO TSUCHIZAKI ${ }^{2}$ \\ Faculty of Agriculture, University of Tokyo, Tanashi, Tokyo $188,{ }^{1}$ Faculty of Agriculture, University of Tokyo, \\ Bunkyo-ku, Tokyo $113,{ }^{2}$ and National Agriculture Research Center, Tsukuba, Ibaraki $305,{ }^{3}$ Japan
}

\begin{abstract}
By using specific primers, the 16S rRNA genes of Japanese mycoplasmalike organisms (MLOs) were amplified by polymerase chain reactions from MLO-enriched fractions of plants infected with each of six different MLOs. Each of the polymerase chain reaction fragments (length, 1,370 nucleotides) was directly sequenced in both strands by using 17 oligonucleotide primers. A phylogenetic tree constructed by using the sequence data showed that these Japanese MLOs are phylogenetically diverse microorganisms that fall into three groups, group I (onion yellows, tomato yellows, mulberry dwarf, and paulownia witches' broom MLOs), group II (tsuwabuki witches' broom MLO), and group III (rice yellow dwarf MLO). A high level of sequence homology (99\%) between the Oenothera hookeri MLO and the severe strain of the western aster yellows MLO on the one hand and group I MLOs on the other indicates that the $O$. hookeri MLO and the severe strain of the western aster yellows MLO belong to group I and suggests that these MLOs, isolated from two geographically separated locations, descended from a very similar ancestor. Although group I contains phylogenetically identical MLOs, the organisms are transmitted by diverse insect vectors. The three MLO groups are more closely related to Acholeplasma laidlawii than to Mycoplasma gallisepticum. Thus, although MLOs are phylogenetically diverse, they are evolutionarily distant from other mollicutes. These data, together with other information (including phylogenetic relationships, vector specificity, plant-pathogenic properties, and habitat in plant phloem sieve tubes), suggest that MLOs could be classified into at least three phylogenetic groups (groups I through III).
\end{abstract}

The members of the class Mollicutes are a diverse group of procaryotes that are closely associated with humans, animals, plants, and insects (39). These organisms differ from other procaryotes in their lack of a cell wall and their minute dimensions. They are thought to be the smallest self-replicating organisms. Their genomes range in size from 680 to $1,600 \mathrm{~kb}$ (36). Previous analyses of $16 \mathrm{~S}$ rRNA and 5S rRNA sequences have shown that members of the class Mollicutes are phylogenetically related to gram-positive bacteria $(30$, $40,46,48)$. It has been postulated that the Mollicutes arose by degenerative evolution from clostridium-like ancestors. In addition to their rRNA sequence similarities, the Mollicutes resemble certain clostridia in the low guanine-pluscytosine $(\mathrm{G}+\mathrm{C})$ contents of their genomes.

Mycoplasmalike organisms (MLOs) morphologically resemble culturable mollicutes. They have been associated with numerous plant diseases in more than 300 plant species worldwide (31). Recently, Lim and Sears (24) have suggested that the MLOs are related to the genus Acholeplasma. However, MLOs have not been cultured in vitro (18), and the classification of these organisms has not been determined yet.

Historically, probable MLO disease etiology has been identified mainly by observation of MLOs in plant phloem tissues by electron microscopy. Plant-pathogenic MLOs have been classified historically by the symptoms that they induce in diseased plants and by the specificity of their transmission by insect vectors. Virescence MLOs and decline MLOs cause similar symptoms, including chlorosis, stunting, and shoot proliferation of the host plants. Determination of the plant host ranges of MLOs and the characteristics of vector transmission is time consuming and often

\footnotetext{
* Corresponding author.
}

difficult. This dependence on biological and pathogenic characteristics in the classification of MLOs has caused confusion in the naming and differentiation of these organisms.

The need for a more precise and specific method for MLO classification led to the development of serological and DNA hybridization assays. In recent years, both polyclonal antisera and monoclonal antibodies have been used to detect MLOs in infected hosts by enzyme-linked immunosorbent assays (ELISAs) and immunosorbent electron microscopy $(1,29)$. Another approach for producing MLO-specific diagnostic reagents has been the molecular cloning of MLO chromosomal fragments extracted from MLO-infected plants $(2,3,15,21,44)$ and from vector insects (12). These cloned DNA fragments have been used as hybridization probes to detect pathogenic MLOs in plants and insects and to study the genetic relationships among MLOs.

Differentiation of MLOs based on serological or genetic characteristics gives more reliable information for MLO taxonomy than differentiation based on the symptoms caused in infected hosts. Although use of these techniques allows relative comparisons and differentiation among MLOs, it does not permit identification of specific biological and phylogenetic positions of MLOs in relation to each other and other microorganisms. To address this problem, we performed a molecular phylogenetic analysis of the $16 \mathrm{~S}$ rRNA genes of MLOs. To date, the 16S rRNA gene sequences of two MLOs have been determined $(17,24)$.

In this paper we describe the development of a polymerase chain reaction (PCR) to amplify MLO $16 \mathrm{~S}$ rRNA coding regions. The PCR fragments were sequenced and phylogenetically analyzed.

(A preliminary report of this study was presented at the Meeting of the Phytopathological Society of Japan, Tokyo, Japan, 28 May 1992.) 
TABLE 1. Primers used for PCR amplification and sequencing of 16S rRNA genes of plant-pathogenic mollicutes

\begin{tabular}{|c|c|c|c|c|}
\hline Primer & Sequence $\left(5^{\prime}-3^{\prime}\right)$ & Position $^{a}$ & Length (mer) & $\begin{array}{c}\text { Melting } \\
\text { temp }\left({ }^{\circ} \mathrm{C}\right)^{b}\end{array}$ \\
\hline SN910601 & GTTTGATCCTGGCTCAGGATT & $1-21$ & 21 & 62 \\
\hline $9 \mathrm{~F}$ & GTTTGATCCTGGCTC & $1-16$ & 15 & 46 \\
\hline SN920201 & ATCCTGGCTCAGGATTAA & $6-23$ & 18 & 52 \\
\hline $120 \mathrm{R}$ & GTGTTACTCACCCGT & $103-89$ & 15 & 46 \\
\hline $350 \mathrm{~F}$ & TACGGGAGGCAGCAG & $335-349$ & 15 & 50 \\
\hline $350 R$ & CTGCTGCCTCCCGTAG & 349-334 & 16 & 54 \\
\hline $520 \mathrm{~F}$ & GTGCCAGCAGCCGCGG & $501-516$ & 16 & 58 \\
\hline $520 \mathrm{R}$ & ACCGCGGCTGCTGGC & $517-503$ & 15 & 54 \\
\hline SN910501 & AATATATGGAG(A)GAACACCA(T)GTA(G) & $688-709$ & 22 & 60 \\
\hline $788 \mathrm{~F}$ & ATTAGATACCCTGGTA & $772-787$ & 16 & 44 \\
\hline $920 \mathrm{R}$ & GTCAATTCCTTTGAGTTT & $902-885$ & 18 & 46 \\
\hline $1099 \mathrm{~F}$ & GCAACGAGCGCAACCC & $1074-1089$ & 16 & 54 \\
\hline $1100 \mathrm{R}$ & AGGGTTGCGCTCGTTG & $1090-1075$ & 16 & 52 \\
\hline SN911201 & GATACAATGGCTG & $1209-1221$ & 13 & 38 \\
\hline SN911202 & CAGCCATTGTATC & $1221-1209$ & 13 & 38 \\
\hline SN910502 & AACCCCGAGAACGTATTCACC & $1368-1348$ & 21 & 64 \\
\hline SN910602 & AGGGATACCTTGTTACGACTT & 1494-1374 & 21 & 58 \\
\hline
\end{tabular}

$a$ The numbers of positions are the numbers in the 16S rRNA sequence of MLO group I (Fig. 1).

${ }^{b}$ Each melting temperature was estimated by multiplying the number of $\mathrm{A}+\mathrm{T}$ residues in the sequence by $2^{\circ} \mathrm{C}$ and the number of $\mathrm{G}+\mathrm{C}$ residues by $4^{\circ} \mathrm{C}$ and adding the two numbers.

\section{MATERIALS AND METHODS}

Sources of MLOs. MLO isolates were maintained by inoculation with insect vectors in greenhouse-grown host plants. The onion yellows MLO (OY-MLO) (32) was isolated from field-collected onions infected with the onion yellows organism in Saitama Prefecture. The OY-MLO was maintained in garland chrysanthemum (Chrysanthemum coronarium) and periwinkle (Catharanthus roseus) by inoculation with leafhoppers (Macrosteles orientalis). The tsuwabuki witches' broom MLO (TW-MLO) (9) was isolated from field-collected tsuwabuki (Farfugium japonicum) infected with the tsuwabuki witches' broom organism in Miyazaki Prefecture. The TW-MLO was maintained by inoculation with leafhoppers (Scleroracus flavopictus) in tsuwabuki and garland chrysanthemum. The tomato yellows MLO (TYMLO) (10) was isolated from field-collected tomatoes ( $L y$ copersicon esculentum) infected with the tomato yellows organism in Hiroshima Prefecture. The TY-MLO was maintained in tomatoes and garland chrysanthemum by inoculation with the leafhopper Macrosteles orientalis. The rice yellow dwarf MLO (RY-MLO) (34) (vectors, Nephotettix cincticeps, Nephotettix nigropictus, and Nephotettix virescens) was isolated from field-collected rice (Oryza sativa) infected with the rice yellow dwarf organism in Kagoshima Prefecture. The RY-MLO was maintained in rice plants (Oryza sativa cv. Koshi-hikari) by inoculation with green rice leafhoppers ( $N$. cincticeps). The paulownia witches' broom MLO (PW-MLO) was isolated from Paulownia tomentosa infected with the paulownia witches' broom organism (vectors, Cyrtopeltis tenuis and Halyomorpha mista) (4). The PW-MLO was maintained in paulownia trees. Mulberry (Morus bombycis cv. Wase Midori) tissues were collected from healthy and mulberry dwarf MLO (MD-MLO)-infected mulberries (vectors, Hishimonus sellatus and Hishimonoides sellatiformis) (4). Healthy plants were also grown and used as controls.

Preparation of MLO-enriched fractions and DNA extraction for PCR amplification. MLO-enriched fractions from leaves, current shoots, and bark phloem of 1-year-old mulberry shoots infected with the MD-MLO were obtained by using a previously described procedure $(12,16)$. The best tissue source for the MD-MLO was established by an indirect ELISA performed with a newly prepared antibody from mouse ascitic fluid, using a previously described protocol (49). Since the bark phloem of 1-year-old shoots showed the highest MLO concentration, it was used as the MLO source for woody plants (data not shown). For herbaceous plants, symptomatic young tissues were used. DNA was isolated from MLO-enriched fractions as described by Kuske and Kirkpatrick (16). DNA extracted from healthy plants by the same extraction procedure was used as the experimental control.

Design of PCR and sequencing primers. A search was made for previously published sequence data for the 16S rRNA genes of the Oenothera hookeri MLO (O-MLO) (24), other culturable members of the Mollicutes, rickettsias, Escherichia coli, chloroplasts, and plant mitochondria and the $16 S$-like rRNA sequences of eukaryotes (35) in the GenBank data base (R. 68.0, June 1991) by using a Software Engineering DNASIS system (version 7.01; Hitachi, Tokyo, Japan). On the basis of the aligned 16S rRNA sequences found, a pair of PCR primers (SN910601 and SN910502) were synthesized (Table 1) which exhibited high levels of sequence homology to the conserved $16 \mathrm{~S}$ rRNA sequences of various members of the Mollicutes. For sequencing, an additional 15 specific primers were synthesized (Table 1) and used with the above-described primer pair. Each primer was synthesized by using a DNA synthesizer (model 391; ABI Japan, Tokyo, Japan).

PCR amplification and sequence analysis. Portions (approximately $8 \mathrm{ng}$ ) of DNAs extracted from OY-, TW-, TY-, RY-, MD-, and PW-MLO-infected and healthy plants were used as PCR templates. Amplification was performed in a 100- $\mu$ l PCR reaction mixture containing $250 \mu \mathrm{M}$ dATP, $250 \mu \mathrm{M}$ dGTP, $250 \mu \mathrm{M}$ dCTP, $250 \mu \mathrm{M}$ dTTP, $1 \mu \mathrm{M}$ upstream primer (SN910601), $1 \mu \mathrm{M}$ downstream primer (SN910502) (Table 1), $10 \mu \mathrm{l}$ of $10 \times$ PCR reaction buffer (Promega Corp., Madison, Wis.), 0.5 U of Taq DNA polymerase (Promega), and $100 \mu \mathrm{l}$ of light paraffin liquid (catalog no. 261-32GR; Nacalai Tesque Corp., Tokyo, Japan). The PCR was carried out for 50 cycles with an automated thermal cycler (model TR-100; Taitec Corp., Saitama, Japan) under the following thermocycling 
conditions: in the first cycle, denaturation for $90 \mathrm{~s}$ at $94^{\circ} \mathrm{C}$, ramping over a period of $40 \mathrm{~s}$ to $60^{\circ} \mathrm{C}$, annealing for $2 \mathrm{~min}$ at $60^{\circ} \mathrm{C}$, ramping over a period of $30 \mathrm{~s}$ to $72^{\circ} \mathrm{C}$, and extension for $3 \mathrm{~min}$ at $72^{\circ} \mathrm{C}$; in the continuing cycles, denaturation for $2 \mathrm{~min}$ at $94^{\circ} \mathrm{C}$; and in the final cycle, extension for $7 \mathrm{~min}$ at $72^{\circ} \mathrm{C}$. The denaturing and annealing conditions were the same as those used for the first cycle $(7,41)$. As expected, the oligonucleotide primers amplified a 1,400 -bp region comprising nearly the whole $16 \mathrm{~S}$ rRNA gene.

PCR-amplified DNA fragments of the 16S rRNA were subjected to agarose gel electrophoresis. The 1,400-bp band was excised from the gel, recovered from the gel matrix by phenol extraction, ethanol precipitated, resuspended with a small amount of TE buffer, and stored in a freezer at $-20^{\circ} \mathrm{C}$ until it was used (43). Both strands of each double-stranded DNA fragment were sequenced by using a Sequenase kit (version 2.0; United States Biochemical Corp., Cleveland, Ohio), ${ }^{35}$ S-dATP, and the primers shown in Table 1 . Manganese was used in the sequencing buffer to improve the extension reaction of the commercially supplied protocol (United States Biochemical Corp.) (46).

Sequence alignment and tree construction. The sequences were aligned by using Hitachi DNASIS software. The initial alignment was refined on the basis of the predicted secondary structure of the molecules. The genetic distances of the sequences from each other were estimated by using the $K_{\text {nuc }}$ values (11). A phylogenetic tree was constructed by the neighbor joining method (42), using Methanococcus vannielii as the root organism. Each confidence value was estimated by the bootstrap sampling method (100 replications) (6).

Nucleotide sequence accession numbers. The nucleotide sequences of the 16S rRNA genes from MLO group I (OY-, TY-, MD-, and PW-MLOs), MLO group II (TW-MLO), and MLO group III (RY-MLO) (Fig. 1) have been deposited in the DDBJ, EMBL, and GenBank data libraries under accession numbers D12569, D12580, and 12581, respectively.

\section{RESULTS}

PCR amplification. The PCR amplified 1,400-bp fragments from plants infected with all six MLOs. These amplified DNA fragments were specific for each MLO disease and were not detected in healthy plant samples run in parallel. The amplified DNA fragments were confirmed to be specific for MLO-infected plants and homologous to the 16S rRNA genes of MLOs by Southern and Northern (RNA) hybridization (data not shown). These results confirmed that the PCR fragments contained the MLO 16S rRNA genes.

Determination and comparison of amplified MLO $16 \mathrm{~S}$ rRNA sequences. The approximately 1,370 -nucleotide sequence of each PCR fragment was determined by direct sequencing (Fig. 1) of both strands by using the 17 oligonucleotide primers (Table 1 ). On the basis of the results of an extensive analysis (maximum matching and homology search) in which the DNASIS program was used, the six MLOs analyzed in this study could be placed into three groups, group I (TY-, OY-, MD-, and PW-MLOs; levels of homology with groups II and III, ca. 89.4 and $89.8 \%$, respectively), group II (TW-MLO; level of homology with group III, ca. 93.3\%), and group III (RY-MLO). The O-MLO and the severe strain of the western aster yellows MLO (SAY-MLO), organisms described in the United States, had levels of sequence homology with group I of 99.8 and $99.7 \%$, respectively.

The $\mathrm{G}+\mathrm{C}$ contents of the $16 \mathrm{~S}$ rRNA genes were calculated by using the sequence data (Fig. 1). The $\mathrm{G}+\mathrm{C}$ contents of our six MLO 16S rRNA genes (MLO group I, $47 \mathrm{~mol} \%$; MLO group II, 45 mol\%; MLO group III, 45 mol\%) were almost the same as the $\mathrm{G}+\mathrm{C}$ contents of the $16 \mathrm{~S}$ rRNA genes of the O-MLO (48 mol\%) (24), the SAY-MLO (47 mol\%) (17), and Mycoplasma gallisepticum (46 mol\%) and significantly lower than the $\mathrm{G}+\mathrm{C}$ contents of $E$. coli $(55 \mathrm{~mol} \%)$, Bacillus subtilis (55 mol\%), and Anacystis nidulans (56 mol\%).

A search for sequences homologous to the sequences of the six MLOs was undertaken among all of the available rRNA (16S or 18S) sequences in the GenBank data base, especially the sequences of selected representatives that exhibit relationships in a dendrogram (Fig. 2), including Bacillus subtilis, Methanococcus vannielli, Mycoplasma gallisepticum, Ureaplasma urealyticum, Acholeplasma laidlawii, Spiroplasma citri, and Anaeroplasma varium. Several deletions were identified in the sequences of the MLOs and other genera of Mollicutes compared with eubacteria such as $E$. coli and B. subtilis (data not shown). Most of the sequences in the evolutionarily variable regions of each MLO group, including these deletions, were homologous to neither the sequences of other MLO groups nor the sequences of other Mollicutes genera.

We compared the 16S rRNA signature oligonucleotides of MLO groups I, II, and III with the signature oligonucleotides of the various members of the Mollicutes and other MLOs (O-MLO and SAY-MLO) (Table 2). The signatures were different among the groups, but the group I signature was identical to the O-MLO and SAY-MLO signatures. As previously reported for the United States isolate (O-MLO) (24), Japanese MLOs are more closely related to Acholeplasma laidlawii than to Mycoplasma gallisepticum.

Phylogenetic analysis. Significant differences were found in the 16S rRNA sequences of MLO groups I, II, and III. This suggests that there is phylogenetic diversity in the plantpathogenic, nonculturable MLOs. To find the phylogenetic position of MLOs relative to other members of the class Mollicutes, we analyzed the phylogenetic tree which we constructed by using these 16S rRNA sequences (Fig. 2). Confidence values $(>85 \%)$ for each branch suggested that the phylogenetic tree is reliable. The nucleotide substitution rate $\left(K_{\text {nuc }}\right.$ value $)$ indicates that the rate of evolution is much higher in the MLOs than in B. subtilis and also higher in MLO groups II and III than in the O-MLO, the SAY-MLO, and the MLO group I cluster (Fig. 2). The tree also shows clearly that MLO group I is closely related to the O-MLO (24) and the SAY-MLO (17), while MLO group II is related to MLO group III. Interestingly, this suggests that some geographically isolated MLOs may have evolved from the same or similar ancestors. These MLOs cluster near Acholeplasma laidlawii and Anaeroplasma varium. However, from the comparisons of oligonucleotide catalogs, MLO groups II and III are more closely related to Anaeroplasma varium than to Acholeplasma laidlawii. In contrast, MLO group I is more closely related to Acholeplasma laidlawii (Table 2).

\section{DISCUSSION}

MLOs have been suggested to belong to the class Mollicutes on the basis of such features as small genome size $(600$ to $1,200 \mathrm{kbp})(25,36)$ and low $\mathrm{G}+\mathrm{C}$ content $(23$ to 29.5 mol\%) (25). This suggestion was supported by the results of our phylogenetic analysis, which are also consistent with the results reported previously $(14,24,26,44)$. It has also been suggested that the MLOs are members of the anaeroplasma 


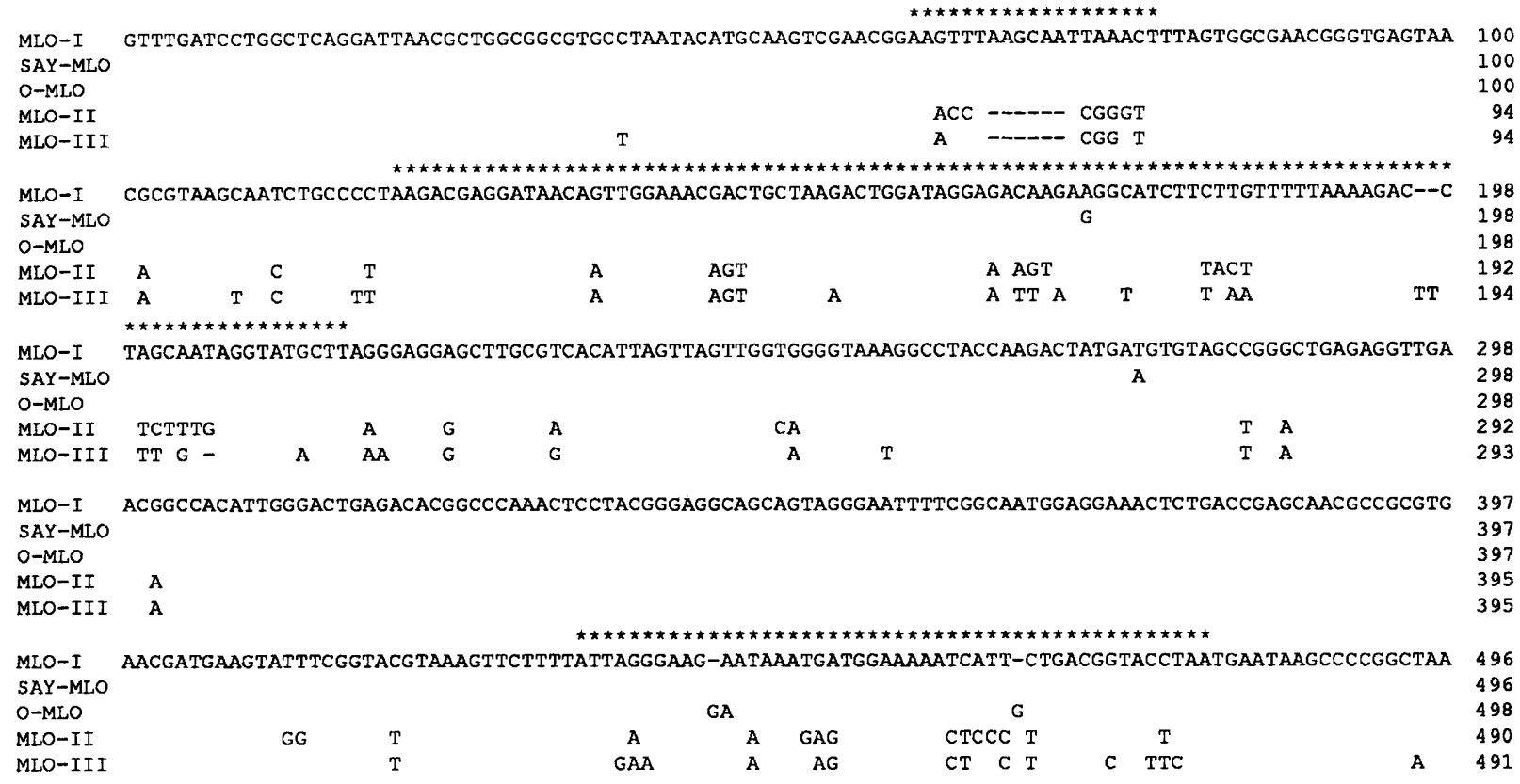

MLO-I CTATGTGCCAGCAGCCGCGGTAATACATAGGGGGCAAGCGTTATCCGGAATTATTGGGCGTAAAgGTGCGTAGgCGgTTAAATAAGTTATGGTCTAAG 596 SAY-MLO

O-MLO

MLO-II

MLO-III

A $\quad$ G

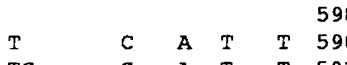

MLO-I TGCAATGCTCAACATTGTGATGCTATAAAAACTGTTTAGCTAGAGTAAGATAGAGGCAAGTGGAATTCCATGTGTAGTGGTAAAATGCGTAAATATATGG 696

SAY-MLO

O-MLO

$\begin{array}{llllclll}\text { MLO-II } & \text { T } & \text { GC } & \text { T } & \text { CGGT } & \text { TG } & \text { G } & \text { A } \\ \text { MLO-III } & \text { T } & \text { G } & \text { T } & \text { C } & \text { CC } & \text { G } & \text { A CAGA }\end{array}$

MLO-I AGgAACACCAGTAGCGAAGgCGgCTTGCTGGGTCTTTACTGACGCTGAGGCACGAAAGCGTGGgGAGCAAACAGGATTAGATACCCTGGTAGTCCACGCC 796

SAY-MLO

$0-M L O$

MLO-II AG T

MLO-III AG T

MLO-I GTAAACGATGAGTACTAAACGTTGGgTAAAA-CCAGTGTTGAAGTTAACACATTAAGTACTCCGCCTGAGTAGTACGTACGCAAGTATGAAACTTAAAGG 895 SAY-MLO

O-MLO

MLO-II

MLO-III

GT $\quad$ C $\quad$ G $\quad$ AC

MLO-III

AATTGACGGGACTCCGCACAAGCGGTGGATCATGTTGTTTAATTCGAAGGTACCCGAAAAACCTCACCAGGTCTTGACATGCTTCTGCAAAGCTGTAGAA

MLO-I ACACAGTGGAGGTTATCAGTTGCACAGGTGGTGCATGGTTGTCGTCAGCTCGTGTCGTGAGATGTTGGGTTAAGTCCCGCAACGAGCGCAACCCTTATTG 1095 SAY-MLO

O-MLO

MLO-II T T A GAAA

MLO-III T T GAAT TCG AGAT

TAA

MLO-I TTAGTTACCAGCACGTAATGGTGGGGACTTTAGCAAGACTGCCAGTGATAAATTGGAGGAAGGTGGGGACGACGTCAAATCATCATGCCCCTTATGACCT 1195 SAY-MLO

O-MLO

MLO-II

MLO-III

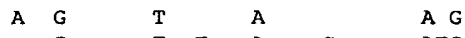

A G

A A

A A A

A TC

MLO-I GGGCTACAAACGTGATACAATGGCTGTTACAAAGGGTAGCTGAAGCGCAAGTTTTTGGCGATCTCAAAAAAACAGTCTCAGTTCGGATTGAAGTCTGCA 1295 SAY-MLO

O-MLO

MLO-II

MLO-III

T A A

A TG

A C

T T A

MLO-I ACTCGACTTCATGAAGTTGGAATCGCTAGTAATCGCGAATCCAGCATGTCGCGGTGAATACGTTCTCGGGGTT 1368

SAY-MLO

O-MLO

MLO-II

MLO-III

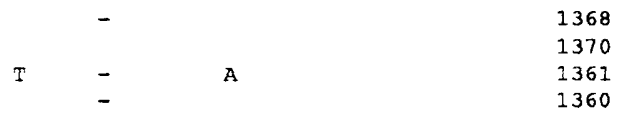




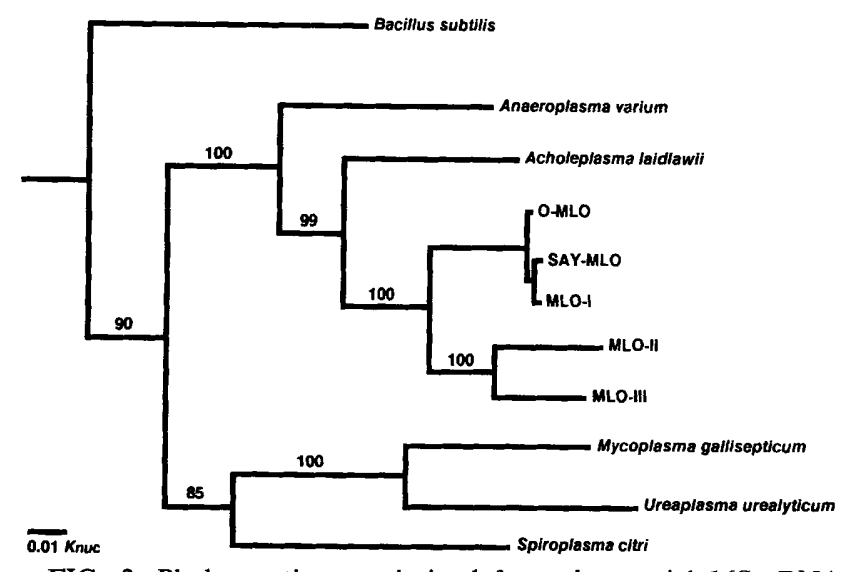

FIG. 2. Phylogenetic tree derived from the partial 16S rRNA sequences of six MLOs and other members of the Mollicutes as described in the text. The number on each branch indicates the confidence value (expressed as a percentage). MLO-I, MLO-II, and MLO-III, MLO groups I, II, and III, respectively.

clade including Acholeplasma laidlawii and Anaeroplasma varium. This suggestion agrees with results of other phylogenetic analyses of 16S rRNA genes and ribosomal protein genes $(17,24,26,27)$. Although the acholeplasmas and MLOs share common hosts (plants and insects), only MLOs are known to reside in plant phloem and have specialized cycles that alternate between sap-sucking insects and plant hosts. Also, MLO genome sizes are approximately one-half the genome sizes of Acholeplasma spp. (36).

Each primer used for PCR in our experiments had a high level of sequence homology with members of the Mollicutes, including members of the genus Spiroplasma, which are associated with plant diseases and arthropods (48) (e.g., Spiroplasma citri, Spiroplasma kunkelii, and Spiroplasma phoeniceum). Spiroplasmas have reportedly been isolated from rice yellow dwarf (38) and several other diseases (5, 37 ), but these isolates may be from mixed infections of spiroplasmas and MLOs (13). None of our amplified fragments had spiroplasma 16S rRNA sequences. From these results, we could find no evidence suggesting that spiroplasmas play any role in the diseases examined in our study.

This is the first study in which as many as six different MLOs were phylogenetically analyzed by sequencing their $16 \mathrm{~S}$ rRNA genes. The Japanese MLOs were shown to be phylogenetically diverse microorganisms that fell into three groups. Lee et al. (20), using specific probes, described three distinct genomic types in the aster yellows MLO strain cluster. On the basis of our results, this cluster should belong to group I, so that these genomic types may be subgroups of group I. We also analyzed other Asian MLOs and several other Japanese MLOs. Our results suggest that almost all Asian MLOs may belong to these three groups (32a).

Although all Japanese group I MLOs have the same 16S rRNA sequence, several of the group I MLOs are transmitted by specific leafhopper vectors $(4,10,32)$ (see Materials and Methods). These observations suggest that insect specificity may involve comparatively recent evolutionary adaptations that have occurred in phylogenetically different MLO groups. However, many of the MLOs multiply in common plants, such as garland chrysanthemum or periwinkle. The results in this paper and our unpublished data (32) suggest that MLOs transmitted by the same vector (e.g., Macrosteles orientalis) have the same 16S rRNA sequence. Similarly, the group II MLO is transmitted by its own specific leafhopper vector hat does not transmit group I MLOs and vice versa $(9,10)$. Since MLOs multiply in vector insects, the affinity of MLO and insect may be important at some hierarchical level for the classification of MLOs.

The MLOs which we used in this research (i) are pleomorphic procaryotes lacking a cell wall as determined by transmission electron microscopy (4); (ii) are found in plant phloem sieve tubes (4) and in general are associated with diseases producing decline symptoms (34), yellowing of leaves, and/or developmental abnormalities $(10,32)$, particularly abnormalities in floral development (32) and meristematic activity $(4,8)$; (iii) are transmitted by phloemfeeding insects, such as leafhoppers $(9,10)$; (iv) are resistant to penicillin and highly susceptible to tetracycline (4); and (v) have small genomes $(25,36)$ and low DNA $\mathrm{G}+\mathrm{C}$ contents (25). DNA sequence analysis of these MLOs produced the following results. The $16 \mathrm{~S}$ rRNA gene of the organisms in each MLO group has some of the unique or rare sequences present in the Mollicutes but lacks some of the highly conserved oligonucleotides found in many genera of the Mollicutes (Table 2$)$. The nucleotide substitution rate $\left(K_{\text {nuc }}\right.$ value) suggests that there has been evolutionary divergence of MLOs from other mollicutes (Fig. 2).

Because the plant-pathogenic MLOs have not been cultured in vitro, their taxonomic placement has been delayed. The phylogenetic information provided by previous studies and the studies reported here indicate that these organisms should not be called MLOs, but that they are simply members of the class Mollicutes. However, it would be premature to suggest a formal nomenclature at this stage. The trivial name "phytoplasma" has recently been informally proposed for these organisms (8). Eventually, perhaps, species concepts for MLOs will be formulated, permitting these organisms to be given binominal epithets. However, until more information is available on specific separation or identification of these various plant pathogens, some type of informal and revisable grouping scheme, such as that proposed in this paper, is appropriate for classification. The substantial molecular data $(19,20,22,23,27)$ now available, including our results, may provide important insights into ecological distribution (33), taxonomy, and molecular diagnosis of MLOs (33) and in vitro culture.

\section{ACKNOWLEDGMENTS}

We gratefully acknowledge S. Kawabe, M. Sato, H. Kawakita, and M. Katsuhara, National Institute of Sericultural and Entomological Science, Tsukuba, Ibaraki, Japan, for supplying healthy and MD-MLO-infected mulberries. We thank K. Ohira, M. Nishiyama, and K. Adachi, Faculty of Agriculture, University of Tokyo, Tokyo,

FIG. 1. Alignments of the 16S rRNA sequences from MLO group I (MLO-I), MLO group II (MLO-II), MLO group III (MLO-III), O-MLO, and SAY-MLO, with adjustments for predicted secondary structure, taking into account deletions and insertions. A blank indicates that the nucleotide is the same as that in the MLO group I sequence. Gaps, included to maximize the alignment, are indicated by dashes. Sequences under asterisks are regions of variability in the primary sequence that are more than $10 \mathrm{bp}$ long. The numbers are the positions of the nucleotides from the $5^{\prime}$ terminus of the sequences shown. 
TABLE 2. Occurrence of oligonucleotides unique to members of the class Mollicutes

\begin{tabular}{|c|c|c|c|c|c|c|c|c|c|c|}
\hline \multirow[b]{2}{*}{ Sequence } & \multicolumn{10}{|c|}{ Occurrence in ${ }^{a}:$} \\
\hline & $\begin{array}{l}\text { O-MLO and } \\
\text { SAY-MLO }\end{array}$ & $\begin{array}{l}\text { MLO } \\
\text { group I }\end{array}$ & $\begin{array}{c}\text { MLO } \\
\text { group II }\end{array}$ & $\begin{array}{c}\text { MLO } \\
\text { group III }\end{array}$ & $\begin{array}{c}\text { Anaeroplasma } \\
\text { varium }\end{array}$ & $\begin{array}{c}\text { Acholeplasma } \\
\text { laidlawii }\end{array}$ & $\begin{array}{c}\text { Spiroplasma } \\
\text { citri }\end{array}$ & $\begin{array}{c}\text { Mycoplasma } \\
\text { capricolum }\end{array}$ & $\begin{array}{l}\text { Ureaplasma } \\
\text { urealyticum }\end{array}$ & $\begin{array}{c}\text { Other } \\
\text { bacteria }\end{array}$ \\
\hline AACG & + & + & + & + & + & + & + & + & + & - \\
\hline UUCUCG & + & + & + & + & - & + & + & + & + & $(-)^{b}$ \\
\hline CAAAUAG & - & - & - & - & - & - & + & + & + & - \\
\hline UACUAAG & - & - & + & + & + & - & + & + & - & - \\
\hline AAUUUUCG & + & + & + & + & + & + & - & - & - & - \\
\hline AUACCCUAG & - & - & - & - & - & - & + & + & + & - \\
\hline CUAACUAUG & + & + & - & - & - & + & + & + & + & - \\
\hline UAUCCCUACG & - & - & - & - & - & + & - & - & - & - \\
\hline UAAUACAUAG & + & + & - & + & - & + & + & + & + & - \\
\hline AAUUUUUCACAAUG & - & - & - & - & - & - & + & + & + & - \\
\hline
\end{tabular}
(48).

a The presence $(+)$ or absence $(-)$ of a sequence in the 16 S rRN gene from an MLO was determined by comparison with existing oligonucleotide catalogs

${ }^{b}(-)$, very rare.

Japan, for technical assistance. We also thank I. Havukkala, National Institute of Agrobiological Resources, Tsukuba, Japan, for critical reading of the manuscript.

\section{REFERENCES}

1. Clark, M. F., A. Morton, and S. L. Buss. 1989. Preparation of mycoplasma immunogens from plants and a comparison of polyclonal associated antigens. Ann. Appl. Biol. 114:111-124.

2. Davis, R. E., E. L. Dally, A. Bertaccini, R. Credi, I.-M. Lee, R. Osler, L. Carraro, and M. Barba. 1992. Cloned DNA probes for specific detection of Italian periwinkle virescence mycoplasmalike organism (MLO) and investigation of genetic relatedness with other MLOs. Phytopathol. Mediterr. 31:5-12.

3. Davis, R. E., W. A. Sinclair, I.-M. Lee, and E. L. Dally. 1992. Cloned DNA probes specific for detection of a mycoplasmalike organism associated with ash yellows. Mol. Plant-Microbe Interact. 5:163-169.

4. Doi, Y., M. Teranaka, K. Yora, and H. Asuyama. 1967. Mycoplasma or P.L.T. group-like microorganisms found in the phloem elements of plants infected with mulberry dwarf, potato witches'-broom, aster yellows or paulownia witches'-broom. Ann. Phytopathol. Soc. Jpn. 33:259-266.

5. Eden-Green, S. J., and H. Waters. 1981. Isolation and preliminary characterization of a spiroplasma from coconut palms in Jamaica. J. Gen. Microbiol. 124:263-270.

6. Felsenstein, J. 1985. Confidence limits on phylogenies: an approach using the bootstrap. Evolution 39:783-791.

7. Innis, M. A., and D. H. Gelfand. 1990. Optimization of PCRs, p. 3-12. In M. A. Innis, D. H. Gelfand, J. J. Sninsky, and T. J. White (ed.), PCR protocols: a guide to methods and applications. Academic Press, San Diego, Calif.

8. International Committee on Systematic Bacteriology Subcommittee on the Taxonomy of Mollicutes. 1993. Minutes of the interim meetings, 1 and 2 August 1992, Ames, Iowa. Int. J. Syst. Bacteriol. 43:394-397.

9. Kato, S., and S. Iwanami. 1990. A new MLO disease, tsuwabuki witches' broom in Nichinan. Ann. Phytopathol. Soc. Jpn. 56:394.

10. Kato, S., T. Shiomi, H. Wakibe, and S. Iwanami. 1988. Tomato yellows transmitted by the leafhopper vector, Macrosteles orientalis Virbaste. Ann. Phytopathol. Soc. Jpn. 54:220-223.

11. Kimura, M. 1980. A simple method for estimating evolutionary rates of base substitutions through comparative studies of nucleotide sequences. J. Mol. Evol. 16:111-120.

12. Kirkpatrick, B. C., D. C. Stenger, T. J. Morris, and A. H. Purcell. 1987. Cloning and detection of DNA from a nonculturable plant pathogenic mycoplasma-like organism. Science 238: 197-200.

13. Kloepper, J. W., and D. G. Garrott. 1980. Relation of in vivo morphology to isolation of plant spiroplasmas. Curr. Microbiol. $4: 365-370$.
14. Kollar, A., and E. Seemüller. 1989. Base composition of the DNA of mycoplasmalike organisms associated with various plant diseases. J. Phytopathol. 127:177-186.

15. Kollar, A., E. Seemüller, F. Bonnet, C. Saillard, and J. M. Bové. 1990. Isolation of the DNA of various plant pathogenic mycoplasmalike organisms from infected plants. Phytopathology 80: 233-237.

16. Kuske, C. R., and B. C. Kirkpatrick. 1990. Identification and characterization of plasmids from the western aster yellows mycoplasmalike organism. J. Bacteriol. 172:1628-1633.

17. Kuske, C. R., and B. C. Kirkpatrick. 1992. Phylogenetic relationships between the western aster yellows mycoplasmalike organism and other procaryotes established by 16S rRNA gene sequence. Int. J. Syst. Bacteriol. 42:226-233.

18. Lee, I.-M., and R. E. Davis. 1986. Prospects for in vitro culture of plant-pathogenic mycoplasma-like organisms. Annu. Rev. Phytopathol. 24:339-354.

19. Lee, I.-M., and R. E. Davis. 1992. Mycoplasmas which infect plants and insects, p. 379-390. In J. Maniloff, R. N. McElhaney, L. R. Finch, and J. B. Baseman (ed.), Mycoplasmas: molecular biology and pathogenesis. American Society for Microbiology, Washington, D.C.

20. Lee, I.-M., R. E. Davis, T.-A. Chen, L. N. Chiykowski, J. Fletcher, C. Hiruki, and D. A. Schaff. 1992. A genotype-based system for identification and classification of mycoplasmalike organisms (MLOs) in the aster yellows MLO strain cluster. Phytopathology 82:977-986.

21. Lee, I.-M., R. E. Davis, and N. D. DeWitt. 1990. Nonradioactive screening method for isolation of disease-specific probes to diagnose plant diseases caused by mycoplasmalike organisms. Appl. Environ. Microbiol. 56:1471-1475.

22. Lee, I.-M., R. E. Davis, and C. Hiruki. 1991. Genetic interrelatedness among clover proliferation mycoplasmalike organisms (MLOs) and other MLOs investigated by nucleic acid hybridization and restriction fragment length polymorphism analyses. Appl. Environ. Microbiol. 57:3565-3569.

23. Lee, I.-M., D. E. Gundersen, R. E. Davis, and L. N. Chiykowski. 1992. Identification and analysis of a genomic strain cluster of mycoplasmalike organisms associated with Canadian peach (eastern) $\mathrm{X}$ disease, western $\mathrm{X}$ disease, and clover yellow edge. J. Bacteriol. 174:6694-6698.

24. Lim, P.-O., and B. B. Sears. 1989. 16S rRNA sequence indicates that plant-pathogenic mycoplasmalike organisms are evolutionarily distinct from animal mycoplasmas. J. Bacteriol. 171:59015906.

25. Lim, P.-O., and B. B. Sears. 1991. The genome size of a plant-pathogenic mycoplasmalike organism resembles those of animal mycoplasmas. J. Bacteriol. 173:2128-2130.

26. Lim, P.-O., and B. B. Sears. 1991. DNA sequence of the ribosomal protein genes rp12 and rps 19 from a plant-pathogenic mycoplasma-like organism. FEMS Microbiol. Lett. 84:71-74. 
27. Lim, P.-O., and B. B. Sears. 1992. Evolutionary relationships of a plant-pathogenic mycoplasmalike organism and Acholeplasma laidlawii deduced from two ribosomal protein gene sequences. J. Bacteriol. 174:2606-2611.

28. Lim, P.-O., B. B. Sears, and K. L. Klomparens. 1992. Membrane properties of a plant-pathogenic mycoplasmalike organism. J. Bacteriol. 174:682-686.

29. Lin, C. P., and T. A. Chen. 1985. Monoclonal antibodies against the aster yellows agent. Science 227:1233-1235.

30. Maniloff, J. 1983. Evolution of wall-less prokaryotes. Annu. Rev. Microbiol. 37:477-499.

31. McCoy, R. E., A. Caudwell, C. J. Chang, T. A. Chen, L. N. Chiykowski, M. T. Cousin, J. L. Dale, G. T. N. de Leeuw, D. A. Golino, K. J. Hackett, B. C. Kirkpatrick, R. Marwitz, H. Petzold, R. C. Sinha, M. Sugiura, R. F. Whitcomb, I. L. Yang, B. M. Zhu, and E. Seemüller. 1989. Plant diseases associated with mycoplasma-like organisms, p. 545-640. In R. F. Whitcomb and J. G. Tully (ed.), The mycoplasmas, vol. 5. Spiroplasmas, acholeplasmas, and mycoplasmas of plants and arthropods. Academic Press, New York.

32. Miyahara, K., M. Matsuzaki, K. Tanaka, and N. Sako. 1982. A new disease of onion caused by mycoplasma-like organism in Japan. Ann. Phytopathol. Soc. Jpn. 48:551-554.

32a.Namba, S. Unpublished data.

33. Namba, S., S. Kato, S. Iwanami, H. Oyaizu, H. Shiozawa, and T. Tsuchizaki. Detection and differentiation of plant-pathogenic mycoplasma-like organisms using polymerase chain reaction. Phytopathology, in press.

34. Nasu, S., M. Sugiura, S. Wakimoto, and T. Iida. 1967. On the etiologic agent of rice yellow dwarf. Ann. Phytopathol. Soc. Jpn. 33:343-344.

35. Neefs, J. M., Y. van de Peer, L. Hendriks, and R. De Wachter. 1990. Compilation of small ribosomal subunit RNA sequences. Nucleic Acids Res. 18(Sequence Suppl.):2237-2317.

36. Neimark, H. C., and C. S. Lange. 1990. Pulsed-field electrophoresis indicates full-length mycoplasma chromosomes range widely in size. Nucleic Acids Res. 18:5443-5448.

37. Nyland, G., and B. C. Raju. 1978. Isolation and culture of a spiroplasma from pear trees affected by pear decline. Phytopathol. News 12:216.

38. Raju, B. C., and G. Nyland. 1978. Effects of different media on the growth and morphology of three newly isolated plant spiroplasmas. Phytopathol. News 12:216.

39. Razin, S. 1985. Molecular biology and genetics of mycoplasmas (Mollicutes). Microbiol. Rev. 49:419-455.

40. Rogers, M. J., J. Simmons, R. T. Walker, W. G. Weisburg, D. R. Woese, R. S. Tanner, I. M. Robinson, D. A. Stahl, G. Olsen, R. H. Leach, and J. Maniloff. 1985. Construction of the mycoplasma evolutionary tree from 5S rRNA sequence data. Proc. Natl. Acad. Sci. USA 82:1160-1164.

41. Saiki, R. K., D. H. Gelfand, S. Stoffe, S. J. Scharf, R. Higuchi, G. T. Horn, K. B. Mullis, and H. A. Erlich. 1988. Primerdirected enzymatic amplification of DNA with a thermostable DNA polymerase. Science 239:487-491.

42. Saitou, N., and M. Nei. 1987. The neighbor-joining method: a new method for reconstructing phylogenetic trees. Mol. Biol. Evol. 4:406-425.

43. Sambrook, J., E. F. Fritsch, and T. Maniatis. 1982. Molecular cloning: a laboratory manual, 2nd ed. Cold Spring Harbor Laboratory Press, Cold Spring Harbor, N.Y.

44. Sears, B. B., P.-O. Lim, N. Holland, B. C. Kirkpatrick, and K. L. Klomparens. 1989. Isolation and characterization of DNA from a mycoplasmalike organism. Mol. Plant-Microbe Interact. 2:175-180.

45. Tabor, S., and C. C. Richardson. 1989. Effect of manganese ions on the incorporation of dideoxynucleotides by bacteriophage T7 DNA polymerase and Escherichia coli DNA polymerase. Proc. Natl. Acad. Sci. USA 86:4076-4080.

46. Weisburg, W. G., J. G. Tully, D. L. Rose, J. P. Petzel, H. Oyaizu, D. Yang, L. Mandelco, J. Sechrest, T. G. Lawrence, J. Van Etten, J. Maniloff, and C. R. Woese. 1989. A phylogenetic analysis of the mycoplasmas: basis for their classification. $J$. Bacteriol. 171:6455-6467.

47. Williamson, D. L., J. G. Tully, and R. F. Whitcomb. 1989. The genus Spiroplasma, p. 71-111. In R. F. Whitcomb and J. G. Tully (ed.), The mycoplasmas, vol. 5. Spiroplasmas, acholeplasmas, and mycoplasmas of plants and arthropods. Academic Press, New York.

48. Woese, C. R., J. Maniloff, and L. B. Zablen. 1980. Phylogenetic analysis of the mycoplasmas. Proc. Natl. Acad. Sci. USA 77:494-498.

49. Xia, Z.-S., H. Kasahara, S. Namba, S. Yamashita, and Y. Doi. 1987. Purification of mulberry dwarf MLO and production of antiserum. Ann. Phytopathol. Soc. Jpn. 53:122. 